\title{
Water Phytoremediation by Sedimentation Using Moringa oleifera Seed Powder to Remove Water Turbidity in Malaysia
}

\author{
Sures Narayasamy, Halimi Mohd Saud* \\ Department of Agriculture Technology, Faculty of Agriculture, University Putra Malaysia, Serdang, Malaysia \\ Email: suressamy@gmail.com, ${ }^{*}$ halimi@agri.upm.edu.my
}

Received 6 February 2014; revised 10 March 2014; accepted 21 March 2014

Copyright (C) 2014 by authors and Scientific Research Publishing Inc.

This work is licensed under the Creative Commons Attribution International License (CC BY). http://creativecommons.org/licenses/by/4.0/

(c) (i) Open Access

\section{Abstract}

The study was carried out to evaluate the efficiency of a natural coagulant that is Moringa oleifera seeds in removing turbid from Malaysian water. Three water samples were used in this study subjected to purification studies using Moringa oleifera seeds that were collected during two different seasons that are dry season (February-March) and rainy season (October-November). The treated water samples were tested for turbidity level, $\mathrm{pH}$ level and color index. The result shows that Moringa oleifera seed collected during drought season has the ability to remove turbidity up to $\mathbf{8 8 . 0 \%}$ and has better color index compared seeds collected during rainy season. The ability of Moringa oleifera seeds protein to act as a magnet assists in attracting the flocks and turbid in the water. Although not as effective as conventional chemicals, Moringa oleifera shows remarkable ability to remove turbid and encourages the use of natural coagulant in water treatment plants as it is cheap and environmental friendly.

\section{Keywords}

Water Purification, Conventional Coagulant, Turbidity, Phytoremediation

\section{Introduction}

In emerging countries throughout South East Asia, Asia and Africa, people almost fully depend upon traditional sources of surface water for their domestic water desires. In the rainy season, the surface water and ground water used for consumption and for domestic use can be highly turbid and comprising suspended material such suspension, mud, heavy metals, bacteria and other microbes. Most of the illnesses in emerging countries are water

${ }^{*}$ Corresponding author.

How to cite this paper: Narayasamy, S. and Saud, H.M. (2014) Water Phytoremediation by Sedimentation Using Moringa oleifera Seed Powder to Remove Water Turbidity in Malaysia. Journal of Agricultural Chemistry and Environment, 3, 74-79. 
associated diseases such cholera, diarrhea, and dysentery. Water borne diseases kill on the average 25,000 people every day in developing countries while millions suffer from the debilitating effects of these diseases.

Therefore, drinking water which is palatable and drinkable is essential to the health and welfare of a community and water from all sources must have some form of sanitization before consumption. Generally, water purification is done using chemical coagulants such Aluminum Sulfate and chlorine. These coagulants are not always available at a sensible amount and value to the populaces of emerging countries. Latest studies [1] [2] have showed a number of disadvantages of aluminum salts such as Alzheimer's disease linked with high aluminum residuals in treated water, extreme sludge production and variations in water chemistry due to reactions with the $\mathrm{OH}-$ and alkalinity of water. Hence, the natural coagulants, such plant parts, rocks, sands and microorganisms are an alternative treatment for coagulation in the distillation process of turbid water and to remove microorganisms.

Seed from Moringa oleifera has been used for water purification and to remove microorganisms in water for many years in rural areas of Africa and Asia. It belongs to the family Moringaceae, consisting of the genus Moringa only, which is composed of fourteen known species. Native to the Northern region of India, Moringa oleifera has been cultivated in several tropical countries such Indonesia, Malaysia, Philippines, Honduras and African countries. The seed pods are legume-like in appearance, but differently from the typical two-sided legumes, these pods are triangular and have a large number of seeds [3]. The M. oleifera is a tall tree up to $10 \mathrm{~m}$ height, with thick stalk and long-petiolate leaves, which are bipinnate with obovate folioles about $3 \mathrm{~cm}$ long. It has edible fruits and leaves, and the roots are described to have abortive properties [4] [5].

The seed kernels of Moringa oleifera contain significant quantities of low molecular-weight that carry a positive charge. When the crushed seeds are added to raw water, the proteins produce positive charges acting like magnets and attracting the predominantly negatively charged particles to form flocs [6]. One of the main advantages of using moringa instead of chemical coagulants is that it can clarify highly turbid murky water and also water of medium and low turbidity as well. Moreover, the moringa also doesn't have any effect on the $\mathrm{pH}$ and conductivity of the water while chemical coagulants will have a drastic shift in the $\mathrm{pH}$ alkalinity [7]. The moringa that kept at room temperature and also in refrigerator for a month perform well in term of removing turbidity compared with seeds that kept for 3 to 5 months [8]. Besides that to date, no proof has found that the seed causes secondary effects on humans. Moreover, it is believe that the seed and also the waste left over can be used as bio organic fertilizers.

This paper studies the effectiveness of Moringa oleifera in reducing the turbidity value in Malaysian water levels.

\section{Materials and Methods}

1) Study location

The present study was conducted at the tissue culture laboratory, Department of Agro technology, Faculty of Agriculture, University Putra Malaysia, Serdang, Selangor Darul Ehsan, Malaysia at room temperature.

2) Water sources under study

The water sources under study were collected from a pond in University Putra Malaysia (Upm, Selangor), a river that joins to Ulu Langat Water collection Dam (Ulu Langat, Selangor), and from Tasik Putih (Kluang, Johor).

3) Moringa oleifera seeds under study

The Moringa oleifera seeds were randomly collected from trees within Kluang, Johor area and also were collected during 2 different seasons that is drought season (February-March) and rainy season (October-November).

\subsection{Seed Powder Preparation}

The seeds were plucked out from the matured seed pots and were allowed to be dried for a week in direct sunlight. Secondly, the seed coats and the wings were removed from the seed kernels. Then crushed and pounded the kernels thoroughly into a fine powder using a mortar. The white color powder was collected and kept in the refrigerator at $4^{\circ} \mathrm{C}$ and used when needed. Approximately, 5 seeds will be equivalent to $1 \mathrm{~g}$. All the selected seeds were free from any insect infection and clean to avoid any contamination during studies. The seeds were allowed to dry 
well in direct sunlight to kill the germs and insects and also to remove the water and moistness in the seeds. The usage of oven or cooker is not recommended because it may kill the protein content in the seeds.

\subsection{Water Phytoremediation Test}

The water samples were tested using $250 \mathrm{ml}$ of conical flask. The conical flask with the water was added with coagulants and must stir for $15 \mathrm{~min}$ at $20 \mathrm{rpm}$ and left undisturbed for 24 hours. The rate or concentration of coagulants that is Moringa oleifera used in this study was 0 (control), $0.25 \mathrm{~g} / \mathrm{L}, 0.5 \mathrm{~g} / \mathrm{L}, 1.0 \mathrm{~g} / \mathrm{L}, 2.0 \mathrm{~g} / \mathrm{L}$ and 4.0 $\mathrm{g} / \mathrm{L}$. This test was done in a clean room to avoid contamination. The data were taken or collected after 24 hours with the recommended parameters.

\subsection{Measurement of Water Quality Parameters}

The turbidity level in the treated water, apparent color and the $\mathrm{pH}$ test were the main parameters used in this studies with water turbidity level was measured using turbid meter, apparent color using visual or naked eye, and $\mathrm{pH}$ value using $\mathrm{pH}$ meter.

\subsection{Statistical Analysis}

The design chooses for this study was Completely Randomize Design (CRD) with 3 replications for each treatment and all the data were analyzed using Analysis of variance method (ANOVA) from Statistical Analysis System Software (SAS version 8.2) at 5\% significant rate. This significant mean variance was differentiated using High Significant Difference Test (HSD).

\section{Results and Discussion}

\subsection{The Percentage of Turbidity Removal}

The percentage of turbidity removal was recorded from the different treatments, found that there were significant differences among them. For water 1 (river that joins to Ulu Langat water collection Dam), the turbidity removal rate by each treatment was significantly different (Table 1) except for the treatment involving moringa with the rate of $1.0 \mathrm{~g} / \mathrm{l}$ and $2.0 \mathrm{~g} / \mathrm{l}$ for seeds that were collected during drought season. There are also no signifi-

\begin{tabular}{|c|c|c|c|c|c|c|}
\hline Period & Moringa oleifera Concentration & Mean/Tukey Grouping & $\mathrm{N}$ & Type & $\mathrm{pH}$ & Color Index \\
\hline Drought & $1.0 \mathrm{~g} / \mathrm{L}$ & $87.6500 \mathrm{a}$ & 2 & t4 & 6.6 & 2 \\
\hline Drought & $2.0 \mathrm{~g} / \mathrm{L}$ & 86.7500 ba & 2 & $\mathrm{t} 5$ & 6.6 & 2 \\
\hline Drought & $4.0 \mathrm{~g} / \mathrm{L}$ & $84.5000 \mathrm{~b}$ & 2 & t6 & 6.5 & 2 \\
\hline Rainy & $2.0 \mathrm{~g} / \mathrm{L}$ & $78.8000 \mathrm{c}$ & 2 & $\mathrm{t} 11$ & 6.8 & 3 \\
\hline Rainy & $1.0 \mathrm{~g} / \mathrm{L}$ & $78.6000 \mathrm{c}$ & 2 & $\mathrm{t} 10$ & 6.8 & 3 \\
\hline Rainy & $4.0 \mathrm{~g} / \mathrm{L}$ & $77.1000 \mathrm{c}$ & 2 & $\mathrm{t} 12$ & 6.8 & 3 \\
\hline Drought & $0.5 \mathrm{~g} / \mathrm{L}$ & $65.6000 \mathrm{~d}$ & 2 & $\mathrm{t} 3$ & 6.8 & 3 \\
\hline Rainy & $0.5 \mathrm{~g} / \mathrm{L}$ & $61.2000 \mathrm{e}$ & 2 & t9 & 6.8 & 4 \\
\hline Drought & $0.25 \mathrm{~g} / \mathrm{L}$ & $24.6000 \mathrm{f}$ & 2 & $\mathrm{t} 2$ & 6.8 & 3 \\
\hline Rainy & $0.25 \mathrm{~g} / \mathrm{L}$ & $19.6000 \mathrm{~g}$ & 2 & t8 & 6.8 & 4 \\
\hline Drought & $0 \mathrm{~g} / \mathrm{L}(\mathrm{ctl})$ & $0.0000 \mathrm{~h}$ & 2 & $\mathrm{t} 1$ (ctl) & 6.8 & 5 \\
\hline Rainy & $0 \mathrm{~g} / \mathrm{L}(\mathrm{ctl})$ & $0.0000 \mathrm{~h}$ & 2 & t7 (ctl) & 6.8 & 5 \\
\hline
\end{tabular}

*Means with the same letter are not significantly different and different letters show significant difference at significant difference at 0.05 significant level. 
cant difference within moringa seeds that were collected during rainy season with the treatment at $1.0 \mathrm{~g} / \mathrm{l}, 2.0 \mathrm{~g} / \mathrm{l}$ and $4.0 \mathrm{~g} / \mathrm{l}$. The highest percentage of turbidity removal was achieved with the use of chemical coagulant that is 98.7\% while with natural coagulant the highest percentage of turbidity removal was $87.1 \%$ achieved with moringa that was collected during drought season with concentration of $1.0 \mathrm{~g} / \mathrm{l}$.

Moreover, water 2 (Water collected from kolam 1 UPM) and water 3 (Water collected from Tasik Putih Kluang, Johor) also shows the similar result as water 1 that is the turbidity removal rate by each treatment was significantly different (Table 2 and Table 3) except for the treatment involving moringa with the rate of $1.0 \mathrm{~g} / \mathrm{l}$ and $2.0 \mathrm{~g} / \mathrm{l}$ for seeds that were collected during drought season and also rainy season. Hence, there are no dif-

Table 2. The percentage of turbidity removal for Upm pond water (water 2) between 2 different moringa harvesting period and also between the concentrations of moringa seed used.

\begin{tabular}{ccccccc}
\hline Period & Moringa oleifera Concentration & Mean/Tukey Grouping & $\mathrm{N}$ & $\mathrm{Type}$ & $\mathrm{pH}$ & Color Index \\
\hline Drought & $0.5 \mathrm{~g} / \mathrm{L}$ & $83.2500 \mathrm{a}$ & 2 & $\mathrm{t} 15$ & 6.5 & 2 \\
Drought & $1.0 \mathrm{~g} / \mathrm{L}$ & $82.9000 \mathrm{ba}$ & 2 & $\mathrm{t} 16$ & 6.5 & 2 \\
Drought & $2.0 \mathrm{~g} / \mathrm{L}$ & $82.0500 \mathrm{~b}$ & 2 & $\mathrm{t} 17$ & 6.5 & 2 \\
Drought & $4.0 \mathrm{~g} / \mathrm{L}$ & $80.6000 \mathrm{c}$ & 2 & $\mathrm{t} 18$ & 6.4 & 2 \\
Rainy & $2.0 \mathrm{~g} / \mathrm{L}$ & $58.3000 \mathrm{~d}$ & 2 & $\mathrm{t} 23$ & 6.6 & 3 \\
Rainy & $1.0 \mathrm{~g} / \mathrm{L}$ & $58.1500 \mathrm{~d}$ & 2 & $\mathrm{t} 22$ & 6.6 & 3 \\
Drought & $0.25 \mathrm{~g} / \mathrm{L}$ & $56.7500 \mathrm{e}$ & 2 & $\mathrm{t} 14$ & 6.6 & 3 \\
Rainy & $4.0 \mathrm{~g} / \mathrm{L}$ & $53.4500 \mathrm{f}$ & 2 & $\mathrm{t} 24$ & 6.6 & 3 \\
Rainy & $0.5 \mathrm{~g} / \mathrm{L}$ & $43.1000 \mathrm{~g}$ & 2 & $\mathrm{t} 21$ & 6.6 & 3 \\
Rainy & $0.25 \mathrm{~g} / \mathrm{L}$ & $37.5500 \mathrm{~h}$ & 2 & $\mathrm{t} 20$ & 6.6 & 4 \\
Drought & $0 \mathrm{~g} / \mathrm{L} \mathrm{(ctl)}$ & $0.0000 \mathrm{I}$ & 2 & $\mathrm{t} 13(\mathrm{ctl})$ & 6.6 & 4 \\
Rainy & $0 \mathrm{~g} / \mathrm{L} \mathrm{(ctl)}$ & $0.0000 \mathrm{I}$ & 2 & $\mathrm{t} 19(\mathrm{ctl})$ & 6.6 & 4 \\
\hline
\end{tabular}

${ }^{*}$ Means with the same letter are not significantly different and different letters show significant difference at significant difference at 0.05 significant level.

Table 3. The percentage of turbidity removal for Tasik Putih (water 3) between 2 different moringa harvesting period and also between the concentrations of moringa seed used.

\begin{tabular}{ccccccc}
\hline Period & Moringa oleifera Concentration & Mean/Tukey Grouping & $\mathrm{N}$ & Type & $\mathrm{pH}$ & Color Index \\
\hline Drought & $1.0 \mathrm{~g} / \mathrm{L}$ & $88.5000 \mathrm{~b}$ & 2 & $\mathrm{t} 28$ & 7 & 2 \\
Drought & $2.0 \mathrm{~g} / \mathrm{L}$ & $87.5500 \mathrm{~b}$ & 2 & $\mathrm{t} 29$ & 7 & 2 \\
Drought & $4.0 \mathrm{~g} / \mathrm{L}$ & $85.3500 \mathrm{c}$ & 2 & $\mathrm{t} 30$ & 7 & 3 \\
Rainy & $1.0 \mathrm{~g} / \mathrm{L}$ & $79.4000 \mathrm{~d}$ & 2 & $\mathrm{t} 34$ & 7.2 & 3 \\
Rainy & $2.0 \mathrm{~g} / \mathrm{L}$ & $79.1000 \mathrm{~d}$ & 2 & $\mathrm{t} 35$ & 7.2 & 3 \\
Rainy & $4.0 \mathrm{~g} / \mathrm{L}$ & $78.4500 \mathrm{~d}$ & 2 & $\mathrm{t} 36$ & 7.1 & 3 \\
Rainy & $0.5 \mathrm{~g} / \mathrm{L}$ & $76.5500 \mathrm{e}$ & 2 & $\mathrm{t} 33$ & 7.3 & 4 \\
Drought & $0.5 \mathrm{~g} / \mathrm{L}$ & $73.6000 \mathrm{f}$ & 2 & $\mathrm{t} 27$ & 7.2 & 3 \\
Drought & $0.25 \mathrm{~g} / \mathrm{L}$ & $56.3000 \mathrm{~g}$ & 2 & $\mathrm{t} 26$ & 7.2 & 4 \\
Rainy & $0.25 \mathrm{~g} / \mathrm{L}$ & $46.4500 \mathrm{~h}$ & 2 & $\mathrm{t} 32$ & 7.3 & 4 \\
Drought & $0 \mathrm{~g} / \mathrm{L}(\mathrm{ctl})$ & $0.0000 \mathrm{i}$ & 2 & $\mathrm{t} 25(\mathrm{ctl})$ & 7.3 & 5 \\
Rainy & $0 \mathrm{~g} / \mathrm{L}(\mathrm{ctl})$ & $0.0000 \mathrm{i}$ & 2 & $\mathrm{t} 31(\mathrm{ctl})$ & 7.3 & 5 \\
\hline
\end{tabular}

"Means with the same letter are not significantly different and different letters show significant difference at significant difference at 0.05 significant level. 
ferences between using $1.0 \mathrm{~g} / \mathrm{l}$ and $2.0 \mathrm{~g} / \mathrm{l}$ of seeds to treat high turbidity water. This study also revealed that the seeds that collected during drought season have better water turbidity removal ability compared with seeds that were collected during rainy season. This is because the polyelectrolyte level present in the kernel that attracts the turbid is high during drought or dry season as discovered by Fuglie.

Furthermore, the highest turbidity removal rate for water 2 was obtained at moringa seed concentration of 0.5 $\mathrm{g} / \mathrm{l}$ but statistical analysis shows there were no significant difference between $0.5 \mathrm{~g} / \mathrm{l}$ and $1.0 \mathrm{~g} / \mathrm{l}$ (Table 2). The highest turbidity removal rate can be achieved at $0.5 \mathrm{~g} / \mathrm{l}$ because the initial turbidity for water 2 is 170 NTU that is considered medium turbidity. The highest turbidity removal rate for water 3 is at moringa seed concentration of $1.0 \mathrm{~g} / \mathrm{l}$. The turbidity removal rate pattern is similar for both water 1 and water 3 because both water 1 and water 3 that has turbidity >250 NTU. Other than that both water 1 and water 3 shows there is no significant differences between $2.0 \mathrm{~g} / \mathrm{l}$ and $4.0 \mathrm{~g} / \mathrm{l}$ for moringa seeds that collected during rainy season and dry season (Table 1 and Table 3). Therefore, we can conclude that for high turbidity water the best moringa concentration to be used is $2.0 \mathrm{~g} / \mathrm{l}$ with the seeds must be collected during dry season. This situation also shows us that the initial water turbidity did play a role in finding the suitable concentration of Moringa oleifera.

\subsection{Apparent Color Index}

The initial apparent color for water from water 1 (River that joins to Ulu Langat water collection Dam) and water 3 (Water collected from Tasik Putih Kluang, Johor) is index 5 (Plate 1) and has been reduced to index 2 (Plate 1) with using moringa seeds that harvested during drought season and reduced to index 3 (Plate 1) with seeds harvested during rainy season. Meanwhile, the initial turbidity for water 2 (Water collected from kolam 1 UPM) is index 4 (Plate 1) and managed to show index 2 (Plate 1) with drought season seeds and index 3 (Plate 1) for rainy season seeds. The apparent color index shows lower index with the increase in Moringa oleifera seed concentration because the mud, colloids and microorganisms in the water are attracted towards the polyelectrolyte layer when moringa is added in the water and forms sediment sludge at the bottom of the conical flask.

\section{3. pH Value}

The initial $\mathrm{pH}$ value for all the water samples studied were range from 6.8 to 7.3 which is within the edible water $\mathrm{pH}$ that is 6.0 - 8.0. For, the seeds that harvested during rainy season, there were no changes in the $\mathrm{pH}$ value for water 1 (River that joins to Ulu Langat water collection Dam) and water 2 (Water collected from kolam 1 UPM), and for water 3 (Water collected from Tasik Putih Kluang, Johor) it changed from 7.3 to 7.1. With the adding of Moringa oleifera seeds that collected during dry season to purify water there is a slight change in the $\mathrm{pH}$ for water 1 where the $\mathrm{pH}$ reduced from 6.8 to 6.5 with the addition of $4.0 \mathrm{~g} / \mathrm{l}$, for river 2 the $\mathrm{pH}$ shift from 6.6 to 6.4 and for water 3 the $\mathrm{pH}$ move from 7.3 to 7.0. Although, there is a slight shift in the $\mathrm{pH}$ value but it did not modify the chemistry of the water where the water remains in neutral state. This is because Moringa oleifera is a natural coagulant that did not released any chemicals in the water and it only react in the physical way where the polyelectrolyte present in the kernels attract the turbid and microorganisms.

\section{Conclusion}

It has been prove that the Moringa oleifera seeds that collected during drought season show extraordinary result in removing the turbidity up to $88.0 \%$ with the dosage of $1.0 \mathrm{~g} / \mathrm{l}$. There is an advantage in using Moringa oleife$r a$ because it is a natural coagulant and environmental friendly compared to chemical coagulants that has left the

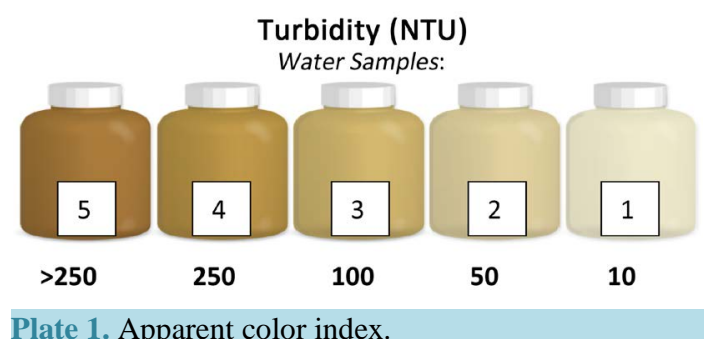


residual at the base of the treatment plans and remains there for years to come. While, Moringa oleifera will become feed for water bond fauna and nutrient for flora in water or even will decay in the water to forms fossils. Moringa also should be regards as significant, sustainable, ecological and affordable method towards water treatments and to provide clean and safer water for cheap for people in poorer countries and also to rural populations where they consume untreated waters. Therefore, future research or study needs to be done on moringa on increasing its ability to hold microbes for a certain period of time and also to develop Moringa oleifera as a coagulant not only in water treatment plans but also in oil purifying plans and in sewage treatment plans. Furthermore, more research needs to be done on the sediment sludge left over after the water treatment to develop it as animal feed and also as phyto-bio fertilizer.

\section{References}

[1] Katayon, S., Megat Mohd Noor, M.J., Asma, M., Thamer, A.M., Liew Abdullah, A.G., Idris, A., Suleyman, A.M., Aminuddin, M.B. and Khor, B.C. (2004) Effects of Storage Duration and Temperature of Moringa oleifera Stock Solution on Its Performance in Coagulation. International Journal of Engineering \& Technology, 146-151.

[2] Ndabigengsere, A. and Narasiah, K. (1996) Influence of Operating Parameters on Turbidity Removal by Coagulation with Moringa oleifera Seeds. Environmental Technology, 17, 1103-1112. http://dx.doi.org/10.1080/09593331708616479

[3] Jose, E.S.P., Marcia, M., Tulio, R. and Marcia, S. (2010) Water Treatment by Sedimentation and Slow Fabric Filtration Using Moringa oleifera Seeds. African Journal of Agricultural Research, 5, 1256-1263.

[4] Correa, M. (1984) Dictionalry of Exotic Plant Cultivars in Brasil. Ministry of Agriculture of Brasil, Brasiia.

[5] Schwarz, D. (2000) Water Clarification Using Moringa oleifera. Gate Information Service, Eschborn.

[6] Futi, A.P., Oteino, W.S., Acholla, O.J., Oteino, W.A., Ochieng, O.S. and Mukisira, M.C. (2011) Harvesting Surface Rainwater-Purification Using Moringa oleifera Seed Extracts and Aluminum Sulfate. Journal of Agricultural Extension and Rural Development, 3, 102-112.

[7] Bergman, E., Matsinhe, M., Pearson, N. and Arnoldsson, K.M. (2008) Assessment of Drinking Water Treatment Using Moringa oleifera Natural Coagulant. VATTEN Edition, 64, 137-150.

[8] Katayon, S., Megat Mohd Noor, M.J., Asma, M., Abdul Ghani, L.A., Thamer, A.M., Azni, I., et al. (2006) Effect of Storage Conditions of Moringa oleifera Seeds on Its Performance in Coagulation. Bioresource Technology, 97, 1455-1460. http://dx.doi.org/10.1016/j.biortech.2005.07.031 